\title{
The effect of thiol-disulfide homeostasis in patients undergoing on-pump coronary artery bypass grafting
}

\author{
On-pump koroner arter baypas greftleme yapılan hastalarda tiyol-disülfid homeostazının etkisi
}

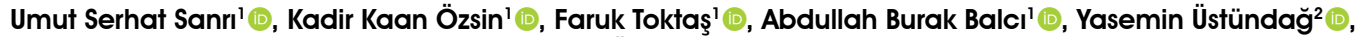 \\ Kağan Huysal ${ }^{2}$ (D, Özcan Erel $^{3}$, , Şenol Yavuz' ${ }^{\circledR}$
}

Institution where the research was done:

University of Health Sciences, Bursa Yüksek İhtisas Training and Research Hospital, Bursa, Turkey

\section{Author Affiliations:}

'Department of Cardiovascular Surgery, University of Health Sciences, Bursa Yüksek Intisas Training and Research Hospital, Bursa, Turkey ${ }^{2}$ Clinical Laboratory, University of Health Sciences, Bursa Yüksek Intisas Training and Research Hospital, Bursa, Turkey ${ }^{3}$ Department of Clinical Biochemistry, Yıldırım Beyazıt University Faculty of Medicine, Ankara, Turkey

\begin{abstract}
Background: In this study, we aimed to investigate the effects of thiol-disulfide homeostasis in patients undergoing on-pump coronary artery bypass grafting.

Methods: Between January 2018 and October 2018, a total of 51 patients (43 males, 8 females; mean age $61.8 \pm 8.7$ years; range, 38 to 78 years) who underwent isolated on-pump coronary artery bypass grafting were included. Thiol-disulfide homeostasis parameters were studied in the preoperative period (T1), 30 min after the removal of cross-clamp (T2), and postoperative sixth $h$ (T3). Hemodynamic parameters such as atrial fibrillation and inotropic support requirement of the patients were evaluated in the postoperative period.

Results: There were significant differences in the measured thiol-disulfide homeostasis parameters at different time points of surgery $(\mathrm{p}<0.001)$. Binary logistic regression analysis showed that $\mathrm{T} 2$-disulfide/native thiol ratio was an independent predictor of the development of postoperative atrial fibrillation $(\mathrm{p}=0.042)$. There were positive and significant correlations between the T2-disulfide levels and cross-clamp time (r:0.307, p=0.029).

Conclusion: Thiol-disulfide homeostasis in patients undergoing on-pump coronary artery bypass grafting changes toward to disulfide. Disulfide levels increase in parallel with prolonged ischemia time. Decreased native thiol and increased disulfide levels during ischemic period may be predictive of postoperative atrial fibrillation.
\end{abstract}

Keywords: Coronary artery bypass grafting, oxidative stress, thioldisulfide homeostasis.

\section{$\ddot{O Z Z}$}

Amaç: Bu çalışmada, on-pump koroner arter baypas greftleme yapılan hastalarda tiyol-disülfid homeostazının etkileri araştırıld1.

Çalışma planı: Ocak 2018 - Ekim 2018 tarihleri arasında izole on-pump koroner arter baypas greftleme yapilan toplam 51 hasta (43 erkek, 8 kadın; ort. yaş $61.8 \pm 8.7$ yıl; dağılım, 38-78 yıl) çalışmaya dahil edildi. Tiyol-disülfid homeostazı parametreleri ameliyat öncesi dönemde (T1), kros-klempin kaldırılmasından $30 \mathrm{dk}$. sonra (T2) ve ameliyat sonrası altıncı saatte (T3) çalışıldı. Ameliyat sonrası dönemde hastalarda atriyal fibrilasyon gelişimi ve inotropik ilaç gereksinimi gibi hemodinamik parametreler değerlendirildi.

Bulgular: Ameliyatın farklı zaman noktalarında ölçülen tiyoldisülfid homeostazı parametreleri arasında önemli farklılıklar vardı ( $\mathrm{p}<0.001)$. İkili lojistik regresyon analizinde T2-disülfid/ nativ tiyol oranının ameliyat sonrası atriyal fibrilasyon gelişimini öngören bağımsız bir değişken olduğu görüldü $(\mathrm{p}=0.042)$. T2-disülfid düzeyleri ile kros-klemp zamanı arasında pozitif ve anlamlı korelasyonlar vard1 (r:0.307, p=0.029).

Sonuç: On-pump koroner arter baypas greftleme yapılan hastalarda tiyol-disülfid homeostazı disülfide doğru değişmektedir. İskemi zamanının uzamasına paralel olarak disülfid düzeyleri artış gösterir. İskemik dönemde azalmış nativ tiyol ve artmış disülfid düzeyleri, ameliyat sonrası atriyal fibrilasyon gelişiminde öngördürücü olabilir.

Anahtar sözcükler: Koroner arter baypas greftleme, oksidatif stres, tiyol-disülfid homeostazı.

Received: March 12, 2019 Accepted: July 15, 2019 Published online: October 23, 2019

Correspondence: Kadir Kaan Özsin, MD. SBÜ Bursa Yüksek İhtisas Eğitim ve Araştırma Hastanesi Kalp ve Damar Cerrahisi Kliniği, 16330 Yıldırım, Bursa, Turkey. Tel: +90344-2235330 e-mail: kaanozsin@yahoo.com 
Oxidative stress occurs during on-pump coronary artery bypass grafting (CABG). High levels of molecular oxygen enter the body during cardiopulmonary bypass (CPB) and reperfusion, followed by inflammation leading to the formation of free oxygen radicals which causes lipid peroxidation, ultimately resulting in an oxidative attack at the cell and tissue level. ${ }^{[1]}$ Existing inflammatory and systemic oxidative stress responses caused by total CPB may cause endothelial damage in many systemic organs which contributes to morbidity and mortality. ${ }^{[2]}$

The imbalance between reactive oxygen species (ROS) production and cellular antioxidant defense system is named as oxidative stress. In the human body, ROS are produced by the aerobic metabolism and a balance between production and inactivation is required. Oxidative stress occurs in case of excess production of ROS, and this may be responsible for many pathological processes and has an impact on the aging process of the body. ${ }^{[3]}$ In stress conditions, ROS levels increase and participate in a variety of chemical reactions, due to their high reactivity. They are involved in cell damage, necrosis, and apoptosis via oxidation of lipids, proteins, and deoxyribonucleic acid (DNA) and also provoke endothelial dysfunction, infiltration, and activation of inflammatory cells. ${ }^{[4]}$

Thiols are a class of organic compounds which contain a sulfhydryl group (-SH) composed of a sulphur atom and a hydrogen atom attached to a carbon atom. Plasma thiol pool is mainly composed of albumin thiols and protein thiols, and to a small degree, low-molecular-weight thiols such as cysteine, cysteinylglycine, glutathione, homocysteine, and $\gamma$-glutamylcysteine. ${ }^{[5]}$ The thiol group of these molecules tends to undergo a wide array of completely reversible or irreversible oxidations and modifications. Under conditions of oxidative stress, thiols can undergo oxidation reaction via oxidants and form disulfide bonds. This disulfide bonds can be reduced again to thiol groups and this alteration maintains the dynamic thiol-disulfide homeostasis. ${ }^{[6]}$ Thiol group containing protein S-glutathionylation emerges as a critical signaling mechanism in cardiovascular diseases, as it regulates numerous physiological processes related with cardiovascular homeostasis, such as myocyte contraction, oxidative phosphorylation, protein synthesis, vasodilatation, glycolytic metabolism, and response to insulin. ${ }^{[4]}$ The role of dynamic thioldisulfide homeostasis has been increasingly shown in many diseases. There is a growing number of evidences that an abnormal thiol-disulfide homeostasis may play role in the pathogenesis of a variety of diseases such as cardiovascular disease, malignancies, rheumatoid arthritis, chronic kidney disease, and acquired immunodeficiency syndrome. ${ }^{[7]}$ Although there are several studies on thiol-disulfide homeostasis, there is no study regarding the relationship between $\mathrm{CABG}$ and thiol-disulfide homeostasis in the literature. In the present study, therefore, we aimed to investigate dynamic thiol-disulfide homeostasis in patients undergoing on-pump CABG.

\section{PATIENTS AND METHODS}

This prospective, observational, randomized clinical study was conducted at the Department of Cardiovascular Surgery of University of Health Science Bursa Yüksek İhtisas Training and Research Hospital between January 2018 and October 2018. A total of 51 patients (43 males, 8 females; mean age $61.8 \pm 8.7$ years; range, 38 to 78 years) who underwent isolated CABG under CPB over 18 years of age were included in this study. Those having risk factors associated with development atrial fibrillation (AF) such as chronic obstructive pulmonary disease (COPD) and valvular heart diseases; those with preoperative cerebrovascular disease, preoperative $\mathrm{AF}$ or flutter, additional surgical intervention, peripheral arterial disease, renal insufficiency, preoperative inotropic or mechanical support, and redo surgery or emergency coronary surgery were excluded from the study. A written informed consent was obtained from each patient. The study protocol was approved by the Ethics Committee of Uludag University (2017-19/42). The study was conducted in accordance with the principles of the Declaration of Helsinki.

Medical history of the patients revealed no chronic diseases which might cause alterations in the oxidative stress parameters. Data including age, gender, history of hypertension, diabetes mellitus, ejection fraction, body surface area, aortic cross-clamp (X-clamp) time, total CPB time, number of anastomosis, inotropic support requirement within the first $24 \mathrm{~h}$ after surgery, intra-aortic balloon pump (IABP) requirement, and development of postoperative AF (PoAF) were recorded.

\section{Anesthesia and surgical procedure}

All patients were monitorized and a radial artery catheter was inserted following the administration of intravenous midazolam (Zolamid ${ }^{\circledR}$; Defarma, Tekirdag, Turkey) (0.05-0.1 mg/kg). Fentanyl (Talinat ${ }^{\circledR}$; Vem, Istanbul, Turkey) $1-2 \mu \mathrm{g} / \mathrm{kg}$ and pentothal $\left(\right.$ Pental $^{\circledR}$ Sodium, Istanbul, Turkey) $5-7 \mathrm{mg} / \mathrm{kg}$ and intravenous rocuronium bromide (Curon ${ }^{\circledR}$, Mustafa Nevzat, Istanbul, Turkey) $0.6 \mathrm{mg} / \mathrm{kg}$ were used for anesthesia induction. 
For intraoperative mechanical ventilation, Primus ${ }^{\circledR}$ (Draeger Medical, Lübeck, Germany) anesthetic machine was used. Maintenance of anesthesia was achieved with midazolam, fentanyl, and rocuronium.

Standard CPB was performed with median sternotomy and mild hypothermia $\left(32^{\circ} \mathrm{C}\right)$. Heparin (300 IU/kg) was administered and activated coagulation time was increased above $400 \mathrm{sec}$. The CPB was performed with two-stage aortovenous cannulation. Also, for thiol measurement, retrograde path through the coronary sinus was inserted. A X-clamp was placed to the ascending aorta and cardiac arrest was provided with cold antegrade cardioplegia (10 to $15 \mathrm{~mL} / \mathrm{kg}$ ) with high potassium. Cardiac arrest was maintained with blood cardioplegia which was given in every 15 to $20 \mathrm{~min}$. The CPB was established with a roller pump with a membrane oxygenator (Maquet, Getinge group, Restalt, Germany) and an arterial line filter at pump flow rates of 2 to $2.4 \mathrm{~L} / \mathrm{min} / \mathrm{m}^{2}$. The distal anastomoses were constructed during a single period of total X-clamp, and proximal anastomoses were established with partial clamping of the aorta. Hot blood shot cardioplegia was given immediately before the X-clamp was removed. Heparin was neutralized by protamine sulfate. In case of any need for inotropic support, dopamine was the first choice. Following the completion of surgery, the patients were taken to the cardiovascular surgery intensive care unit. Standard postoperative care was given to all the patients. Extubation was performed at the earliest stage possible following the provision of hemodynamic stability. Amiodarone was used as the first-choice antiarrhythmic agent in case of a new-onset of AF.

\section{Blood sampling and biochemical analyses}

Laboratory parameters were studied from venous blood samples preoperatively, except for thiol-disulfide homeostasis parameters. Fasting blood samples were taken from an antecubital vein of each patient before operation. The ethylenediaminetetraacetic acid (EDTA) tubes were used for automatic blood count according to the protocol of our hospital. These parameters were measured using an automated hematological analyzer (Coulter LH 780 Analyzer, CA, USA).

For thiol-disulfide homeostasis parameters, serial blood samples were drawn from the coronary sinus before CPB (T1), 30 min after removal of the X-clamp (T2) and were drawn from the central venous catheter in the postoperative sixth $\mathrm{h}$ (T3). The coronary sinus is a small tubular structure anatomically just above the posterior left atrioventricular junction. Following contraction of the myocardium, blood drains into the right atrium via the coronary sinus. Therefore, we preferred coronary sinus blood in sampling, as it includes information related to cardiac metabolism and physical condition. Blood samples were centrifuged at 3,600 rpm for $10 \mathrm{~min}$ and serum plasma samples were removed and stored at $-80^{\circ} \mathrm{C}$ until analysis. Thiol-disulfide homeostasis was measured as defined by Erel and Neselioglu. ${ }^{[7]}$ Following the measurement of the native thiol, disulfide and total thiol amount, disulfide/native thiol percent ratio, disulfide/total thiol percent ratio, native thiol/total thiol percent ratio were calculated.

\section{Definition of thiol-disulfide homeostasis parameters}

Thiols are a class of organic compounds which contain a sulfhydryl group (-SH) consisting of a sulfur atom and a hydrogen atom. They exist in plasma as albumin and protein thiols and this pool is called native thiol. In case of oxidative stress, the sulfhydryl groups of the two thiol groups are joined to compose the disulfide bond. Thus, in case of oxidative stress, the amount of disulfide increases, while the native thiol decreases. The sum of the amount of native thiol and disulfide in the environment is called total thiol.

\section{Statistical analysis}

Statistical analysis was performed using the IBM SPSS version 21.0 software (IBM Corp., Armonk, NY, USA). Continuous variables were expressed in mean \pm standard deviation (SD) and categorical variables were expressed in number and frequency. The Kolmogorov-Smirnov test was used to identify distribution of variables. In dependent groups, based on the normal distribution analysis of data, the paired samples t-test, Wilcoxon signed-rank test, repeated-measures analysis of variance (ANOVA) test, and Friedman test were used to examine the relationship between measured thiol-disulfide homeostasis parameters at different time points. The Pearson's correlation and Spearman's correlation coefficient tests were used to analyze any significant correlation between thiol-disulfide homeostasis parameters and total CPB time and X-clamp time. Development of PoAF and postoperative inotropic support requirement were evaluated using a logistic regression analysis. The receiver operating characteristic (ROC) curve was used for the prediction of PoAF development in patients undergoing isolated CABG. The area under the curve (AUC), sensitivity, and specificity were calculated to analyze the diagnostic value of thiol-disulfide homeostasis parameters. A $p$ value of $<0.05$ was considered statistically significant. 


\section{RESULTS}

Demographic and clinical characteristics of the patients are summarized in Table 1. In total, PoAF developed in 21 patients (41.2\%) during the postoperative period and standard medical cardioversion treatment was administered with amiodarone $(5 \mathrm{mg} / \mathrm{kg})$ for $30 \mathrm{~min}$, followed by $900 \mathrm{mg} / \mathrm{day}$. All patients were discharged with sinusoidal rhythm, except for three (5.9\%). Twenty-six patients $(51 \%)$ received inotropic support (5 to $10 \mu \mathrm{g} / \mathrm{kg} / \mathrm{min}$ dopamine) within the postoperative first $24 \mathrm{~h}$. At the end of the postoperative $48 \mathrm{~h}$, no patient required any inotropic support. Also, we applied IABP to four patients (7.8\%) and removed within postoperative first $48 \mathrm{~h}$ in all of these patients. No early mortality was observed within the postoperative first 30 days.

In the measurement time points (T1, T2, and T3), the changes in thiol-disulfide homeostasis parameters of the patients were compared, and it was observed that these changes were statistically significantly different from each other $(\mathrm{p}=0.017$ for disulfide and $\mathrm{p}<0.001$ for other parameters; repeated measuredANOVA, Friedman test) (Table 2).

In the comparison between $\mathrm{T} 1$ and $\mathrm{T} 2$ measurements, statistically significant differences were observed in terms of all thiol-disulfide homeostasis parameters $(\mathrm{p}<0.001$; paired samples test, Wilcoxon signed-rank test). However, only disulfide levels were not significantly different between the measures $(\mathrm{p}=0.467$; paired samples test) (Table 2). For T2 and T3 measurements, statistically significant differences were found in terms of all thiol-disulfide homeostasis parameters $(p=0.015$ for disulfide and $\mathrm{p}<0.001$ for other parameters; paired samples test, Wilcoxon signed-rank test) (Table 2). In the comparison between $\mathrm{T} 2$ and $\mathrm{T} 3$ measurements,

Table 1. Demographic and clinical characteristics of patients $(n=51)$

\begin{tabular}{|c|c|c|c|}
\hline & $\mathrm{n}$ & $\%$ & Mean \pm SD \\
\hline \multicolumn{4}{|l|}{ Demografic findings } \\
\hline Age (year) & & & $61.8 \pm 8.7$ \\
\hline \multicolumn{4}{|l|}{ Gender } \\
\hline Male & 43 & 84.3 & \\
\hline Body surface area $\left(\mathrm{m}^{2}\right)$ & & & $1.88 \pm 0.2$ \\
\hline Hypertension & 39 & 76.5 & \\
\hline Diabetes mellitus & 28 & 54.9 & \\
\hline Ejection fraction $(\%)$ & & & $50.8 \pm 8.6$ \\
\hline \multicolumn{4}{|l|}{ Operative parameters } \\
\hline Number of anastomosis & & & $3.4 \pm 1.1$ \\
\hline $\mathrm{X}$-clamp time (min) & & & $64.7 \pm 21.3$ \\
\hline Total cardiopulmonary bypass time (min) & & & $93.6 \pm 27.9$ \\
\hline Postoperative atrial fibrillation & $21(41.2)$ & & \\
\hline Inotropic drugs support & $26(51)$ & & \\
\hline Intra-aortic balloon pump support & $4(7.8)$ & & \\
\hline Intensive care unit stay (day) & & & $2.37 \pm 0.6$ \\
\hline Hospital stay (day) & & & $7.2 \pm 0.7$ \\
\hline \multicolumn{4}{|l|}{ Laboratory parameters } \\
\hline Hemoglobin (gr/dL) & & & $13.3 \pm 2.1$ \\
\hline White blood cell $\left(10^{3} / \mu \mathrm{L}\right)$ & & & $8.1 \pm 2.0$ \\
\hline Platelet $\left(10^{3} / \mu \mathrm{L}\right)$ & & & $236.7 \pm 59.9$ \\
\hline C-reactive protein (mg/dL) & & & $10.0 \pm 15.5$ \\
\hline Creatinine (mg/dL) & & & $0.9 \pm 0.4$ \\
\hline Fibrinogen $(\mu \mathrm{g} / \mathrm{mL})$ & & & $397.6 \pm 103.6$ \\
\hline Albumin (g/dL) & & & $3.9 \pm 0.4$ \\
\hline
\end{tabular}

SD: Standard deviation 
Table 2. Measured thiol-disulfide homeostasis parameters and comparisons in different time points

\begin{tabular}{|c|c|c|c|c|}
\hline \multirow[t]{2}{*}{ Parameters } & $\mathrm{T} 1$ & $\mathrm{~T} 2$ & $\mathrm{~T} 3$ & \\
\hline & Mean \pm SD & Mean \pm SD & Mean \pm SD & \\
\hline Native thiol $(\mu \mathrm{mol} / \mathrm{L})$ & $178.4 \pm 43.2$ & $95.3 \pm 45.5$ & $196.2 \pm 43.2$ & \\
\hline Total thiol $(\mu \mathrm{mol} / \mathrm{L})$ & $205.6 \pm 48.1$ & $115.4 \pm 47.5$ & $223.8 \pm 45.5$ & \\
\hline Disulfide $(\mu \mathrm{mol} / \mathrm{L})$ & $11.8 \pm 4.1$ & $11.3 \pm 3.7$ & $13.6 \pm 5.3$ & \\
\hline Disulfide/native thiol & $6.9 \pm 2.9$ & $13.6 \pm 5.4$ & $7.3 \pm 3.3$ & \\
\hline Disulfide/total thiol & $5.8 \pm 2.3$ & $11.1 \pm 5.5$ & $6.2 \pm 2.4$ & \\
\hline \multirow[t]{3}{*}{ Native thiol/total thiol } & $86.7 \pm 4.5$ & $80.0 \pm 11.3$ & $87.4 \pm 4.8$ & \\
\hline & $\mathrm{T} 1-\mathrm{T} 2$ & $\mathrm{~T} 1-\mathrm{T} 3$ & $\mathrm{~T} 2-\mathrm{T} 3$ & $\mathrm{~T} 1-\mathrm{T} 2-\mathrm{T} 3$ \\
\hline & $p$ & $p$ & $p$ & $p$ \\
\hline Native thiol & $<0.001^{*}$ & $=0.018^{*}$ & $<0.001^{*}$ & $<0.001 \mathrm{~J}$ \\
\hline Total thiol & $<0.001^{*}$ & $=0.021 *$ & $<0.001^{*}$ & $<0.0019$ \\
\hline Disulfide & $=0.467^{*}$ & $=0.035^{*}$ & $=0.015^{*}$ & $=0.017 \mathrm{~J}$ \\
\hline Disulfide/native thiol & $<0.001 \dagger$ & $<0.001 \dagger$ & $<0.001 \dagger$ & $<0.001 \ddagger$ \\
\hline Disulfide/total thiol & $<0.001^{*}$ & $=0.395^{*}$ & $<0.001^{*}$ & $<0.0019$ \\
\hline Native thiol/total thiol & $<0.001^{*}$ & $=0.415^{*}$ & $<0.001^{*}$ & $<0.001 \mathrm{~d}$ \\
\hline
\end{tabular}

T: Time courses of plasma concentrations of thiol-disulfide homeostasis parameters (T1: Before cardiopulmonary bypass period, T2: 30 min after removal of X-clamp, T3: six h after surgery); * Paired samples test; $†$ Wilcoxon signed-rank test; I Repeated measured-ANOVA; $\ddagger$ Friedman test.

there were statistically significantly different in terms of native thiol, total thiol, disulfide and disulfide/ native thiol percent ratio $(\mathrm{p}=0.018, \mathrm{p}=0.021, \mathrm{p}=0.035$, and $\mathrm{p}<0.001$, respectively; paired samples test, Wilcoxon signed-rank test), but were not significantly different for disulfide/total thiol percent ratio and native thiol/total thiol percent ratio $(\mathrm{p}=0.395$ and $\mathrm{p}=0.415$, respectively; paired samples test) (Table 2).

In the correlation analysis, we found that there was a significant correlation only between the disulfide levels and $\mathrm{X}$-clamp time ( $\mathrm{rp}=0.307, \mathrm{p}=0.029$; Pearson correlation).

Table 3. Binary logistic regression analysis for postoperative atrial fibrillation

\begin{tabular}{|c|c|c|c|c|c|c|c|c|}
\hline \multirow[b]{3}{*}{ Variables } & \multicolumn{4}{|c|}{ Univariate analysis } & \multicolumn{4}{|c|}{ Multivariate analysis } \\
\hline & \multirow[t]{2}{*}{$p$} & \multirow{2}{*}{$\frac{\operatorname{Exp}(\mathrm{B})}{\text { Odds ratio }}$} & \multicolumn{2}{|c|}{$95 \% \mathrm{CI}$} & \multirow[t]{2}{*}{$p$} & \multirow{2}{*}{$\frac{\operatorname{Exp}(\mathrm{B})}{\text { Odds ratio }}$} & \multicolumn{2}{|c|}{$95 \% \mathrm{CI}$} \\
\hline & & & Lower & Upper & & & Lower & Upper \\
\hline Hypertension & 0.025 & 11.579 & 1.361 & 98.537 & 0.037 & 10.442 & 1.148 & 94.974 \\
\hline Diabetes mellitus & 0.161 & 2.286 & 0.719 & 7.266 & & & & \\
\hline Ejection fraction & 0.538 & 1.021 & 0.955 & 1.091 & & & & \\
\hline Total CPB time & 0.378 & 1.009 & 0.989 & 1.030 & & & & \\
\hline $\mathrm{X}$-clamp time & 0.613 & 1.007 & 0.981 & 1.034 & & & & \\
\hline Native thiol (T2) & 0.064 & 0.983 & 0.965 & 1.001 & & & & \\
\hline Total thiol (T2) & 0.050 & 0.982 & 0.963 & 1.000 & & & & \\
\hline Disulfide (T2) & 0.777 & 1.022 & 0.880 & 1.186 & & & & \\
\hline Disulfide/native thiol (T2) & 0.021 & 1.159 & 1.023 & 1.314 & 0.042 & 1.150 & 1.005 & 1.315 \\
\hline Disulfide/total thiol (T2) & 0.262 & 1.072 & 0.950 & 1.210 & & & & \\
\hline Native thiol/total thiol (T2) & 0.800 & 0.994 & 0.946 & 1.044 & & & & \\
\hline
\end{tabular}

$\operatorname{Exp}(\mathrm{B})$ : Exponentiation of the B coefficient; CI: Confidence interval; CPB; Cardiopulmonary bypass; T: Time courses of plasma concentrations of thioldisulfide homeostasis parameters (T2: 30 min after removal of X-clamp). 
Table 4. Binary Logistic regression analysis for inotropic support requirement

\begin{tabular}{|c|c|c|c|c|c|c|c|c|}
\hline \multirow[b]{3}{*}{ Variables } & \multicolumn{4}{|c|}{ Univariate analysis } & \multicolumn{4}{|c|}{ Multivariate analysis } \\
\hline & \multirow[t]{2}{*}{$p$} & \multirow{2}{*}{$\frac{\operatorname{Exp}(\mathrm{B})}{\text { Odds ratio }}$} & \multicolumn{2}{|c|}{$95 \% \mathrm{CI}$} & \multirow[t]{2}{*}{$p$} & \multirow{2}{*}{$\frac{\operatorname{Exp}(\mathrm{B})}{\text { Odds ratio }}$} & \multicolumn{2}{|c|}{$95 \% \mathrm{CI}$} \\
\hline & & & Lower & Upper & & & Lower & Upper \\
\hline Ejection fraction & 0.002 & 0.862 & 0.786 & 0.946 & 0.002 & 0.849 & 0.765 & 0.941 \\
\hline Total CPB time & 0.830 & 1.002 & 0.982 & 1.022 & & & & \\
\hline X-clamp time & 0.854 & 0.998 & 0.972 & 1.024 & & & & \\
\hline Native thiol (T2) & 0.754 & 0.998 & 0.986 & 1.010 & & & & \\
\hline Total thiol (T2) & 0.687 & 0.998 & 0.986 & 1.009 & 0.658 & 0.996 & 0.980 & 1.013 \\
\hline Disulfide (T2) & 0.700 & 0.971 & 0.838 & -1.126 & & & & \\
\hline Disulfide/native thiol (T2) & 0.511 & 1.036 & 0.933 & 1.150 & 0.396 & 0.931 & 0.790 & 1.098 \\
\hline Disulfide/total thiol (T2) & 0.811 & 0.988 & 0.893 & 1.093 & & & & \\
\hline Native thiol/total thiol (T2) & 0.810 & 1.006 & 0.957 & 1.057 & & & & \\
\hline
\end{tabular}

$\operatorname{Exp(B):~Exponentiation~of~the~B~coefficient;~CI:~Confidence~interval;~CPB:~Cardiopulmonary~bypass;~T:~Time~courses~of~plasma~concentrations~of~thiol-~}$ disulfide homeostasis parameters (T2: 30 minutes after removal of X-clamp).

Table 5. Result of receiver operating characteristic curve analysis for thiol-disulfide homeostasis parameters at T2 for predicting postoperative atrial fibrillation

\begin{tabular}{lccccccc}
\hline Test result variable(s) & AUC & $\begin{array}{c}\text { Sensitivity } \\
\%\end{array}$ & $\begin{array}{c}\text { Specificity } \\
\%\end{array}$ & Cut-off value & $p$ & Asymptotic 95\% CI \\
\hline Postoperative atrial fibrillation & & & & & & Lower & Upper \\
Native thiol (T2) & 0.321 & 28.6 & 66.7 & 101.800 & 0.031 & 0.168 & 0.475 \\
Disulfide (T2) & 0.524 & 57.1 & 60.0 & 10.950 & 0.774 & 0.361 & 0.687 \\
Disulfide/native thiol ratio (T2) & 0.699 & 66.7 & 80.0 & 13.713 & 0.016 & 0.544 & 0.854 \\
\hline
\end{tabular}

CI: Confidence interval; AUC: Area under the curve; T: Time courses of plasma concentrations of Thiol-Disulfide homeostasis parameters (T2: 30 min after removal of X-clamp).

Risk factors related to the development of PoAF were included in the univariate logistic regression analysis which showed that the PoAF was significantly correlated with hypertension (OR [odds ratio] $=11,579$, 95\% CI [confidence interval]: 1,361-98,537, $\mathrm{p}=0.025)$ and disulfide/native thiol percent ratio $(\mathrm{OR}=1,159$, 95\% CI: 1,023-1,314, $\mathrm{p}=0.021$ ), but was not correlated with another (Table 3). Similar to the results in the univariate analysis, hypertension $(\mathrm{OR}=10,442$, 95\% CI: 1.148-94.974, $\mathrm{p}=0.037)$ and disulfide/native thiol percent ratio $(\mathrm{OR}=1,150,95 \% \mathrm{CI}: 1,005-1,315$, $\mathrm{p}=0.042$ ) were identified as an independent predictor of PoAF after CABG surgery in the multivariate analysis (Table 3). In terms of inotropic support, in binary logistic regression analysis, we found that ejection fraction was an independent predictor $(\mathrm{OR}=0.849$, 95\% CI: 0.765-0.941, p=0.002) (Table 4).

According to the measurements of the $\mathrm{T} 2$ period changes, the ROC curve analysis demonstrated that disulfide/native thiol percent ratio values of 13,713 or above could predict development of PoAF with a sensitivity of $66.7 \%$ and a specificity of $80 \%$ (AUC: 0.699, 95\% CI: 0.544-0.854, log-rank $\mathrm{p}=0.016$ ), while native thiol levels of 101,800 or below could predict development PoAF with a sensitivity of $28.6 \%$ and a specificity of $66.7 \%$ (AUC: $0.321,95 \%$ CI: $0.168-0.475$, $\log$-rank $\mathrm{p}=0.031)$ (Table 5, Figure 1).

\section{DISCUSSION}

Major targets of in vivo reactive oxygen species are protein thiols and for thiol-disulfide exchange is occured oxidative conversion of thiols into disulfides and reduction. Thiol-disulfide pool is the main factor of intracellular redox homeostasis and is necessary for both antioxidant defense and redox regulation of cell signaling ${ }^{[8]}$ The functional group of cysteine is a thiol group $(\mathrm{SH})$ which able to undergo a wide array of modifications due to its chemical reactivity. Most 


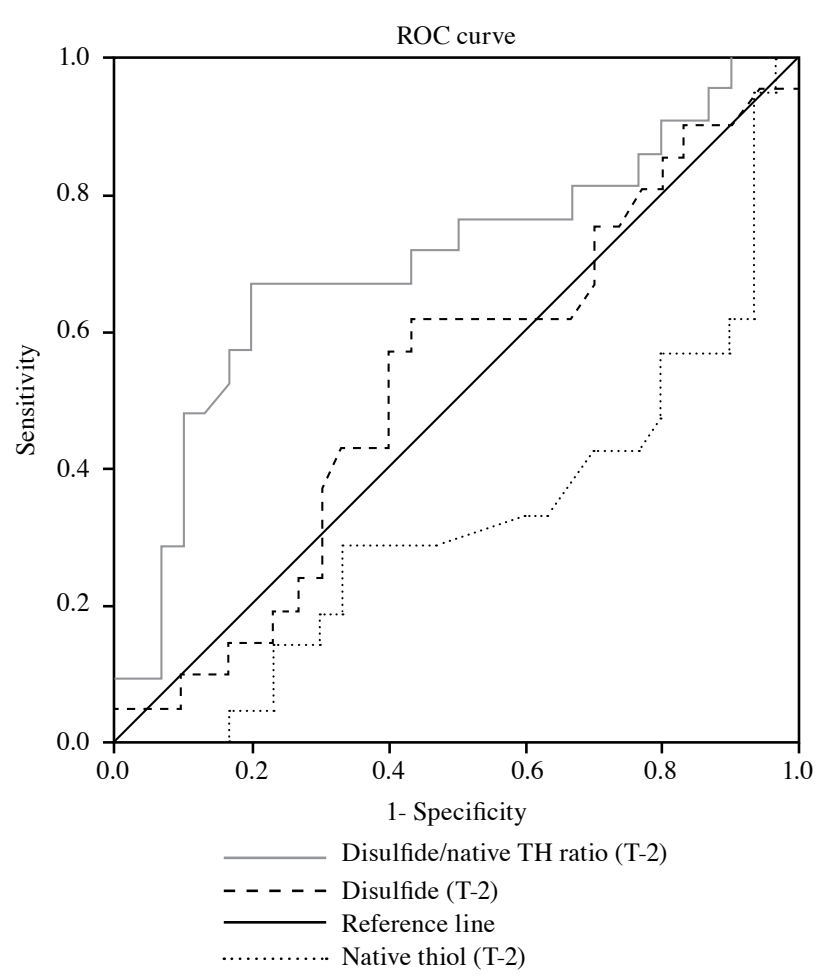

Figure 1. Receiver operating characteristic curve (ROC) and area under the curve for predicting development of postoperative atrial fibrillation for native thiol, disulfide and disulfide/native thiol ratio at $\mathrm{T} 2$.

of these modifications include the reversible oxidation of the thiol to sulfenic acid (SOH), and intra- and intermolecular disulfides between polypeptides and glutathione-polypeptide (glutathionylation). ${ }^{[9]}$ Entire protein glutathionylation increases after ischemiareperfusion, and most of the glutathionylation events occur during the early reperfusion period. Therefore, disturbance in protein glutathionylation status may contribute to the etiology of cardiovascular diseases, such as myocardial infarction, cardiac hypertrophy, and atherosclerosis. ${ }^{[4]}$

In this study, we found significant differences between measured thiol-disulfide homeostasis parameters at different time points of on-pump CABG. Binary logistic regression analysis revealed that T2-disulfide/native thiol ratio was an independent predictor of the development of PoAF. The T2- disulfide/native thiol ratio with a cut-off value of 13.713 or above for the prediction of development of PoAF was found with a sensitivity of $66.7 \%$ and a specificity of $80 \%$ in the ROC analysis. In addition, we observed a positive and significant correlation between the T2- disulfide levels and the X-clamp time.
During on-pump CABG with cardioplegic arrest, global ischemia occurs in the heart. This process is related with the systemic inflammatory response and oxygen-derived free radicals which may cause myocardial damage and many disorders. ${ }^{[10]}$ The primary targets of ROS are the -SH groups of sulfur containing amino acids (i.e., cysteine, methionine) in proteins. The -SH groups are oxidized while in the same environment with ROS and form reversible disulfide bonds. This is the first indicator of radicalmediated protein oxidation. ${ }^{[1]]}$ Kundi et al. ${ }^{[12]}$ found that there were significant positive correlations between peak troponin I levels and disulfide levels, and disulfide/native thiol and disulfide/total thiol ratios. In a recent study, Altiparmak et al. ${ }^{[13]}$ found that native and total thiol levels significantly decreased in patients with critical coronary artery disease, and these reductions were significantly correlated with the severity of coronary artery disease. In addition, their results showed that decreased native thiol levels were independent predictors of coronary artery disease. In our study, in patients undergoing on-pump CABG, we measured the parameters of thiol-disulfide homeostasis in three different time points including pre-ischemia period (T1), ischemia period (T2) and post-ischemia period (T3). During the T2 period, thiol levels decreased, while the levels of disulfide increased; however, in the $\mathrm{T} 3$ period, when the ischemia ended, thiol levels increased $(\mathrm{p}<0.001)$, whereas disulfide levels decreased $(\mathrm{p}=0.017)$ (Table 2$)$. These changes were caused by the thiol-disulfide homeostasis in ischemic T2 period and the results were statistically significant. We found a positive and significant correlation between X-clamp time and increased disulfide levels in the correlation analysis $(r=0.307, p=0.029)$. These findings are consistent with other studies with thiol-disulfide homeostasis and are the first results of thiol-disulfide homeostasis in on-pump CABG.

Cardiovascular risk factors such as hypertension, congestive heart failure, coronary artery disease, and diabetes are associated with AF and low-grade inflammation. Inflammation and oxidative stress appear to have an important role in the pathogenesis of AF in obesity and other metabolic disorders, such as diabetes. ${ }^{[14]}$ Postoperative AF is a frequent complication emerging in the early postoperative period after CABG. Postoperative complications and hemodynamic changes may extend the healing process of patients. Recently, pathophysiological pathways involving the inflammatory and oxidative processes have been studied in the development of AF. ${ }^{[15]}$ Numerous studies have shown that specific circulating 
inflammatory markers such as C-reactive protein (CRP) and interleukin (IL)-6 are associated with a higher risk of $\mathrm{AF}$ in the general population and in patients undergoing heart surgery. ${ }^{[16]}$ Therefore, we evaluated the relationship between the parameters of the thiol-disulfide homeostasis in the ischemic T2 period with the PoAF and postoperative inotropic support requirement. In the univariate and multivariate logistic regression analyses, we found that disulfide/ native thiol ratio was an independent predictor of PoAF, but we found no statistical significance between this ratio and postoperative inotropic support requirement (Table 3, Table 4). In the ROC curve analysis, we found that native thiol levels, disulfide/native thiol ratio and disulfide levels are important in predicting PoAF development (Table 5, Figure 1). In the literature, we did not find any study about the relationship between the parameters of thiol-disulfide homeostasis and postoperative complications and the requirement for inotropic support after CABG. However, Bektas et al. ${ }^{[17]}$ reported that thiol levels reduced in acute ischemic strokes and that thiol donors could reduce stroke-related neuronal damage and improve healing.

Apart from cardiovascular diseases, in many different diseases such as Alzheimer's disease, ${ }^{[18]}$ cerebral ischemia, ${ }^{[19]}{ }^{\mathrm{COPD}},{ }^{[20]}$ basal cell $\mathrm{Ca},{ }^{[21]}$ and prediabet, ${ }^{[22]}$ thiol-disulfide homeostasis as oxidative stress marker has been investigated, and the results obtained from these studies are consistent with our results. Ateş et al. ${ }^{[23]}$ demonstrated that dynamic thioldisulfide homeostasis shifts toward disulfide formation as a result of thiol oxidation in patients with masked hypertension. In another study, disulfide levels were found to be increased in newly diagnosed hypertension patients. ${ }^{[24]}$ In parallel to these studies, we found that the disulfide/native thiol ratio and the presence of hypertension were independent predictors of PoAF development after on-pump CABG surgery in the logistic regression analysis.

Nonetheless, our study has several limitations. First, the sample size was small with a single-center design. Second, there was no control group. Third, our aim was to investigate how thiol-disulfide homeostasis changed in the inflammatory and ischemia-reperfusion processes in different stages of on-pump CABG and that these changes had any effect on the postoperative period. However, we were unable to measure other antioxidant parameters such as ischemia-modified albumin, total antioxidant status, total oxidant status, and other oxidative stress markers.

In conclusion, cardiopulmonary bypass is an unfamiliar procedure for the body. Non-specific inflammatory response demonstrates its signs from the very first minutes of the procedure. An ischemiareperfusion process begins simultaneously with placing the cross-clamp on the aorta. A possible relationship between dynamic thiol-disulfide homeostasis and some cardiovascular diseases has been proposed. To the best of our knowledge, this study is the first clinical study in the English literature investigating dynamic thiol-disulfide homeostasis in patients undergoing on-pump coronary artery bypass grafting. In this study, we found that there were significant differences between the measured thiol-disulfide homeostasis parameters in different periods of on-pump surgery. T2- disulfide/native thiol ratio was an independent predictor of the development of postoperative atrial fibrillation. Deterioration of the balance in thiol/ disulfide homeostasis in favor of disulfide may provide information about the inflammatory response in on-pump coronary artery bypass grafting and damage due to ischemia-reperfusion process. However, further studies on treatment modalities for thiol-mediated decreased thiol and increased disulfide levels are still needed, particularly in patients with prolonged crossclamp period.

\section{Declaration of conflicting interests}

The authors declared no conflicts of interest with respect to the authorship and/or publication of this article.

\section{Funding}

The authors received no financial support for the research and/or authorship of this article.

\section{REFERENCES}

1. Atalay A, Yalınız H, Göçen U, Topçuoğlu MŞ, Salih OK, Baştürk Y, et al. The effects of normoxic and hyperoxic cardiopulmonary bypass on oxidative stress in cyanotic pediatric patients. Turk Gogus Kalp Dama 2013;21:898-904.

2. Hatemi AC, Çeviker K, Tongut A, Özgöl İ, Mert M, Kaya A. Oxidant status following cardiac surgery with phosphorylcholine-coated extracorporeal circulation systems. Oxid Med Cell Longev 2016;2016:3932092.

3. Ustundag Y, Huysal K, Kahvecioglu S, Demirci H, Yavuz S, Sambel M, et al. Establishing reference values and evaluation of an in-house ferric reducing antioxidant power (FRAP) colorimetric assay in microplates. Eur Res J 2016;2:126-31.

4. Pastore A, Piemonte F. Protein glutathionylation in cardiovascular diseases. Int J Mol Sci 2013;14:20845-76.

5. Turell L, Radi R, Alvarez B. The thiol pool in human plasma: the central contribution of albumin to redox processes. Free Radic Biol Med 2013;65:244-53.

6. Cremers CM, Jakob U. Oxidant sensing by reversible disulfide bond formation. J Biol Chem 2013;288:26489-96.

7. Erel O, Neselioglu S. A novel and automated assay for thiol/ disulfide homeostasis. Clin Biochem 2014;47:326-32. 
8. Nagy P. Kinetics and mechanisms of thiol-disulfide exchange covering direct substitution and thiol oxidation-mediated pathways. Antioxid Redox Signal 2013;18:1623-41.

9. Comini MA. Measurement and meaning of cellular thiol:disufhide redox status. Free Radic Res 2016;50:246-71.

10. Karahan SC, Koramaz I, Altun G, Uçar U, Topbaş M, Menteşe A, et al. Ischemia-modified albumin reduction after coronary bypass surgery is associated with the cardioprotective efficacy of cold-blood cardioplegia enriched with N-acetylcysteine: a preliminary study. Eur Surg Res 2010;44:30-6.

11. Dean RT, Fu S, Stocker R, Davies MJ. Biochemistry and pathology of radical-mediated protein oxidation. Biochem $\mathbf{J}$ 1997;324:1-18.

12. Kundi H, Ates I, Kiziltunc E, Cetin M, Cicekcioglu H, Neselioglu S, et al. A novel oxidative stress marker in acute myocardial infarction; thiol/disulfide homeostasis. Am J Emerg Med 2015;33:1567-71.

13. Altıparmak IH, Erkuş ME, Sezen H, Demirbag R, Gunebakmaz O, Kaya Z, et al. The relation of serum thiol levels and thiol/disulfide homeostasis with the severity of coronary artery disease. Kardiol Pol 2016;74:1346-53.

14. Korantzopoulos P, Letsas KP, Tse G, Fragakis N, Goudis CA, Liu T. Inflammation and atrial fibrillation: A comprehensive review. J Arrhythm 2018;34:394-401.

15. Gutierrez A, Van Wagoner DR. Oxidant and inflammatory mechanisms and targeted therapy in atrial fibrillation: An update. J Cardiovasc Pharmacol 2015;66:523-9.

16. Liu T, Li G, Li L, Korantzopoulos P. Association between C-reactive protein and recurrence of atrial fibrillation after successful electrical cardioversion: a meta-analysis. J Am Coll Cardiol 2007;49:1642-8.

17. Bektas H, Vural G, Gumusyayla S, Deniz O, Alisik M, Erel O. Dynamic thiol-disulfide homeostasis in acute ischemic stroke patients. Acta Neurol Belg 2016;116:489-94.

18. Gumusyayla S, Vural G, Bektas H, Deniz O, Neselioglu $\mathrm{S}$, Erel O. A novel oxidative stress marker in patients with Alzheimer's disease: dynamic thiol-disulfide homeostasis. Acta Neuropsychiatr 2016;28:315-20.

19. Ivanov AV, Alexandrin VV, Paltsyn AA, Nikiforova KA, Virus ED, Luzyanin BP, et al. Plasma low-molecular-weight thiol/disulfide homeostasis as an early indicator of global and focal cerebral ischaemia. Redox Rep 2017;22:460-6.

20. Eroğlu O, Badem ND, Baccıŏlu A, Cömertpay E, Neşelioğlu $S$, Erel Ö. Significance of thiol/disulfide homeostasis and ischemia modified albumin levels in chronic obstructive pulmonary disease. Eur Res J 2019;5:250-7.

21. Demirseren DD, Cicek C, Alisik M, Demirseren ME, Aktaş A, Erel O. Dynamic thiol/disulfide homeostasis in patients with basal cell carcinoma. Cutan Ocul Toxicol 2017;36:278-82.

22. Ates I, Kaplan M, Inan B, Alisik M, Erel O, Yilmaz N, et al. How does thiol/disulfide homeostasis change in prediabetic patients? Diabetes Res Clin Pract 2015;110:166-71.

23. Ateş İ, Ozkayar N, Altay M, Yilmaz FM, Topçuoğlu C, Alışık $\mathrm{M}$, et al. Is disulfide/thiol ratio related to blood pressure in masked hypertension? Clin Exp Hypertens 2016;38:150-4.

24. Ates I, Ozkayar N, Inan B, Yilmaz FM, Topcuoglu C, Neselioglu S, et al. Dynamic thiol/disulfide homeostasis in patients with newly diagnosed primary hypertension. J Am Soc Hypertens 2016;10:159-66. 